\title{
PARTISIPASI MASYARAKAT LOKAL DALAM PENGELOLAAN EKOWISATA MANGROVE DI KELURAHAN OESAPA BARAT KOTA KUPANG
}

\author{
(Local Community Participation Of Mangrove Ecotourism Management \\ At West Oesapa Regency-Kupang)
}

\author{
Maria Grace Lawe Siu ${ }^{1)}$, Siti Amanah ${ }^{1)}$, Nyoto Santoso ${ }^{2 *}$ \\ ${ }^{1}$ Program Studi Ilmu Pengelolaan SumberDaya Alam dan Lingkungan IPB, Gedung Sekolah \\ Pascasarjana Lantai II Kampus IPB Baranangsiang Bogor 16144, Indonesia \\ ${ }^{1}$ Departemen Sains Komunikasi Pengembangan Masyarakat Fakultas Ekologi Manusia IPB, Jl. Lingkar \\ Akademik Kampus IPB Dramaga Bogor 16680, Indonesia \\ ${ }^{2}$ Departemen Konservasi Sumberdaya Hutan dan Ekowisata IPB, Jl. Raya Dramaga Kampus IPB \\ Dramaga Bogor 16680, Indonesia \\ *e-mail: gracelawesiu@gmail.com
}

\begin{abstract}
Ecotourism in the Mangrove area of West Oesapa Village can be an advantage of alternative to the development of ecotourism within the framework of tourism management and its development by the area manager and the local community. The development of ecotourism is undivided by the participation or social involvement in planning and implementing program to support the preservation of mangrove forests, the preservation of the coastal environment, and the fulfillment of the socio-economic requirement. Therefore, social participation is primary element to analyzed data. This research used descriptive qualitative methods through the distribution of questionnaires to related parties and then compiled them quantitatively to showed certainty value. As a result, the level of social participation in the management of mangrove ecotourism in order to develop ecotourism areas in West Oesapa Village is poor. Supporting of the preservation is required by all related parties to provide knowledge and concern so that, programs of the ecotourism development program in the West Oesapa Village can run as expected.
\end{abstract}

Keywords: Ecotourism, mangrove ecotourism, social participation

\section{Abstrak}

Ekowisata di kawasan mangrove Kelurahan Oesapa Barat dapat menjadi alternatif manfaat pengembangan ekowisata dalam rangka pengelolaan dan pengembangan wisata dari pihak pengelola kawasan maupun pihak masyarakat sekitar. Pengembangan ekowisata ini tidak dapat dipisahkan dari partisipasi atau keterlibatan masyarakat dalam perencanaan maupun implementasinya guna mendukung pelestarian kawasan hutan mangrove, pelestarian lingkungan pesisir, dan pemenuhan kebutuhan sosial ekonomi masyarakat. Oleh karena itu, partisipasi masyarakat menjadi unsur penting dalam pengelolaan data. Penelitian ini menggunakan metode deskriptif kualitatif melalui penyebaran kuisioner kepada pihak terkait dan kemudian dikaji secara kuantitatif untuk menunjukkan nilai nyata. Hasil penelitian menunjukkan tingkat partisipasi masyarakat dalam pengelolaan ekowisata mangrove guna mengembangkan kawasan ekowisata di Kelurahan Oesapa Barat sangat rendah. Dukungan dari pengelola dibutuhkan oleh semua pihak terkait untuk memberikan pengetahuan dan kepedulian agar program pengembangan ekowisata Kelurahan Oesapa Barat dapat berjalan sesuai harapan.

Kata kunci: Ekowisata, ekowisata mangrove, partisipasi masyarakat. 


\section{PENDAHULUAN}

Nusa Tenggara Timur (NTT) merupakan salah satu provinsi di Indonesia yang juga memiliki hutan mangrove. Berdasarkan data Balai Pengelolaan Hutan Mangrove (BPHM, 2011), kondisi hutan mangrove di NTT cukup memprihatinkan, sebagian besar mengalami kerusakan dengan tingkat yang berbeda yaitu sebanyak $8.285,10$ ha atau 20,40\% (kategori rusak berat), $19.552,44$ ha atau $48,14 \%$ (kategori rusak ringan), dan $12.776,57$ ha atau $31,46 \%$ (kategori baik). Data ini menunjukkan bahwa tekanan terhadap hutan mangrove sangat tinggi karena hanya sepertiga dari total luas hutan mangrove yang masih dalam kondisi baik, selebihnya telah mengalami kerusakan sebagai dampak dari berbagai bentuk pemanfaatan. Berdasarkan hasil wawancara (Surya, 2009) dengan Joseph Diaz sebagai Kepala Dinas Kehutanan NTT, dari 40.695 ha luas hutan mangrove di NTT sekitar 9.989 ha $(2,25$ $\%$ ) sudah banyak yang mengalami tekanan diantaranya akibat penebangan hutan mangrove oleh masyarakat untuk kebutuhan bahan bangunan, kayu bakar, dan pembangunan tambak.

Salah satu daerah di NTT yang memiliki hutan mangrove di sepanjang garis pantai adalah Kota Kupang, khususnya daerah Oesapa Barat. Kawasan mangrove di Kelurahan Oesapa Barat, merupakan bagian kawasan pengelolaan oleh Dinas Kelautan dan Perikanan Kota Kupang. Hutan mangrove di Kelurahan Oesapa Barat dalam perkembangannya saat ini telah menjadi salah satu tujuan wisata bagi masyarakat umum di Kota Kupang dan sekitarnya.

Ekowisata di kawasan Mangrove Kelurahan Oesapa Barat dapat menjadi alternatif pengembangan ekowisata dalam kerangka pengelolaan dan pengembangan wisata baik oleh pihak pengelola kawasan maupun pihak masyarakat sekitar. Kegiatan ekowisata adalah alternatif yang efektif untuk menanggulangi permasalahan kerusakan lingkungan di ekosistem mangrove seperti tingkat eksploitasi yang berlebihan oleh masyarakat dengan menciptakan alternatif ekonomi bagi masyarakat sekitar (Saputra, 2017).

Objek wisata hutan mangrove di kawasan pantai Oesapa Barat ini, hingga saat ini masih merupakan satu-satunya ekowisata hutan mangrove yang ada di kota Kupang, yang di kelola oleh Dinas Kelautan dan Perikanan Kota Kupang dengan memberdayakan masyarakat sekitar. Salah satu yang menjadi unggulan di destinasi ini yaitu pemandangan alam dengan lebatnya hutan mangrove yang dapat di nikmati dengan berkeliling melalui jembatan yang telah disiapkan oleh pihak pengelola. Di area hutan mangrove ini juga terdapat tambak garam yang juga merupakan salah satu atraksi di destinasi ini.

Namun seiring berjalannya waktu pengelolaan pada ekowisata mangrove ini dapat dikatakan kurang maksimal, seperti semakin berkurang atau rusaknya sarana dan prasarana dan pembangunan yang bergerak ditempat sehingga berdampak pada jumlah kunjungan 
wisatawan pada destinasi ini (Sagala \& Pellokila, 2019). Kendala lain dalam pengelolaan ekowisata mangrove saat ini yaitu belum adanya peraturan daerah yang mengatur tentang ekowisata mangrove sehingga kegiatan pengelolaan dan pengembangan ekowisata belum mempunyai arah tujuan yang jelas serta rendahnya tingkat pendidikan masyarakat yang mengelola ekowisata mangrove berdampak pada kurangannya pengetahuan masyarakat tentang mengelola sumber daya alam.

Dalam pengembangan ekowisata ini tidak lepas dari partisipasi atau keterlibatan masyarakat dalam perencanaan, maupun implementasinya guna menunjang kelestarian kawasan hutan mangrove, pelestarian lingkungan pesisir, dan pemenuhan kebutuhan sosial ekonomi masyarakat. Dengan demikian segala potensi daerah dan sumber daya masyarakat lokal turut tergali dan berkembang (Pitana \& Putu, 2005).

Hasil penelitian Lio \& Stanis (2017) memperlihatkan bahwa tingkat partisipasi masyarakat di Kelurahan Oesapa Barat tergolong rendah, baik dalam hal pemanfaatan maupun penyuluhan tentang pentingnya keberadaan hutan mangrove. Pemerintah telah berupaya mengadakan kegiatan yang melibatkan masyarakat, tetapi masyarakat belum begitu berpartisipasi secara aktif. Seharusnya dalam pengelolaan ekowisata, masyarakat di sekitar kawasan harus aktif terlibat, karena masyarakat sekitarlah yang terkena dampak langsung dari kegiatan tersebut. Pariwisata yang berbasis masyarakat harus memperhatikan partisipasi masyarakat lokal yang merupakan syarat mutlak untuk tercapainya pembangunan pariwisata berkelanjutan.

Mengingat pentingnya partisipasi masyarakat lokal dalam pengelolaan ekowisata mangrove, maka perlu adanya kajian mengenai partisipasi masyarakat dalam pengelolaan ekowisata mangrove di Kelurahan Oesapa Barat, Kota Kupang. Tujuan penelitian ini untuk mengetahui tingkat partisipasi masyarakat lokal dalam pengelolaan ekowisata mangrove di Kelurahan Oesapa Barat. Partisipasi masyarakat ini tidak terlepas dari kondisi sosial ekonomi masyarakat dan persepsi masyarakat, selain itu faktor pendorong partisipasi juga memiliki kontribusi terhadap tingkat partisipasi masyarakat. Manfaat penelitian untuk memberikan data-data dan informasi terkait partisipasi masyarakat dalam pengelolaan ekowisata mangrove di Kelurahan Oesapa Barat, sehingga dapat menjadi masukan bagi pengelolaan ekowisata mangrove.

\section{METODE PENELITIAN}

Penelitian ini dilaksanakan di kelurahan Oesapa Barat yang berlokasi di wilayah Kecamatan Kelapa Lima, Kota Kupang Provinsi Nusa Tenggara Timur. Obyek penelitian ini adalah masyarakat yang tinggal disekitar kawasan ekowisata mangrove. Sebanyak 30 responden diambil untuk diwawancara dengan menggunakan kuesioner sebagai alat bantu untuk memperoleh data. Responden diambil Pengambilan data dilakukan secara purposive sampling. Purposive sampling 
adalah proses pengambilan data dengan pertimbangan tertentu. Pertimbangan tertentu dalam penelitian ini yaitu masyarakat yang tinggal di sekitar kawasan ekowisata mangrove (RT02) dan merupakan kepala keluarga.

Teknik pengumpulan data dilakukan dengan observasi, wawancara, kuisioner dan studi kepustakaan. Observasi adalah kegiatan pengumpulan data dengan melakukan penelitian langsung terhadap kondisi lingkungan objek penelitian yang mendukung kegiatan penelitian, sehingga didapat gambaran secara jelas tentang kondisi objek penelitian tersebut (Siregar, 2013)

Wawancara merupakan proses memperoleh keterangan untuk tujuan penelitian dengan cara tanya jawab dan bertatap muka antara pewawancara dan informan. wawancara dalam penelitian ini adalah wawancara mendalam. Wawancara mendalam (in-depth interview) adalah data yang diperoleh terdiri dari kutipan secara langsung dari orang-orang tentang pengalaman, pendapat dan pengetahuan informan penelitian. Kuisioner adalah teknik pengumpulan data yang dilakukan dengan cara memberi seperangkat pertanyaan atau peryataan tertulis kepada responden untuk dijawab (Sugiyono, 2014).

Kuesioner yang digunakan dalam penelitian ini adalah kuesioner dengan model Skala Likert. Studi kepustakaan diperoleh dari bebagai referensi yang relevan dengan penelitian yang dijalanakan dan teknik ini berdasarkan text book ataupun jurnal ilmiah tentang partisipasi masyarakat dan ekowisata mangrove. Teknik analisis data dilakukan secara deskriptif. Dengan metode deskriptif, peneliti memungkinkan untuk melakukan hubungan antar variabel, mengembangkan generalisasi dan teori yang memiliki validasi universal (Singarimbun \& Effendi, 2014).

\section{HASIL DAN PEMBAHASAN}

Lokasi Ekowisata Mangrove terletak di kawasan Oesapa Barat, Kota Kupang, Nusa Tenggara Timur Kupang. Destinasi ekowisata diresmikan dan di buka pada bulan Februari 2016. Ekowisata Hutan mangrove awalnya dikembangkan dengan bantuan dari Pemerintah Italia melalui International Fund for Agriculture Development (IFAD) yakni organisasi yang bergerak di bidang pembangunan masyarakat pesisir yang memberikan suntikan dana kepada pemerintah Kota Kupang melalui Dinas Kelautan dan Perikanan Kota Kupang dan dikelola oleh kelompok pengelolaan sumberdaya (PSDA) yang beranggotakan masyarakat setempat. Ekowisata mangrove memang dibangun dalam kaitannya dengan pemeliharaan ekosistem mangrove dalam wilayah Kelurahan ini, sekaligus untuk peningkatan ekonomi bagi masyarakat miskin di Kelurahan Oesapa Barat. Tujuan utama proyek ini adalah pengurangan kemiskinan, peningkatan pertumbuhan ekonomi masyarakat miskin pesisir dan pulau-pulau kecil, serta pengembangan dan pengelolaan sumberdaya. Hutan mangrove ini memiliki luas kurang lebih 32.42 ha.

Kelurahan Oesapa Barat masuk dalam wilayah Kecamatan Kelapa Lima 
terbentuk berdasarkan Peraturan Daerah Kota Kupang Nomor 6 Tahun 2006, terdiri dari 7 RW dan 19 RT. Selanjutnya pada tahun 2009 dengan mempertimbangkan pendekatan pelayanan, maka dilakukan pemekaran 3 wilayah RT menjadi 6 RT. Kelurahan Oesapa Barat mempunyai luas wilayah 6 $\mathrm{KM}\left(6.000 \mathrm{M}^{2}\right)$.

\section{Potensi Ekowisata Hutan}

\section{Mangrove Oesapa Barat}

Potensi wisata adalah berbagai sumber daya yang terdapat di sebuah daerah tertentu yang bisa di kembangkan menjadi atraksi wisata. Potensi wisata yang terdapat dikawasan objek wisata hutan mangrove Oesapa Barat adalah pemandangan alam hutan mangrove yang luas, wisata air, pantai serta tambak garam yang dapat dijadikan atraksi wisata yang ada di destinasi tersebut. Terdapat 6 jenis mangrove yang pada kawasan ekowisata yaitu jenis Xylocarpus mollucensis, Sonneratia alba, Sonneratia caseolaris, Avicennia alba, Ceriops tagal, Rhizophora mucronata. Hutan mangrove yang ada di Kelurahan Oesapa Barat juga dapat dimanfaatkan sebagai sarana pembelajaran bagi wisatawan, pelajar dan mahasiswa yang datang berkunjung.

\section{Kondisi Sosial Ekonomi Masyarakat}

Aspek kondisi sosial ekonomi masyarakat yang dikaji meliputi umur, jumlah anggota keluarga, tingkat pendidikan, lama tinggal, pekerjaan serta pendapatan. Masyarakat yang dijadikan sebagai responden sebanyak 30 orang yang terdiri atas 24 orang pria dan 6 orang wanita. Data kondisi sosial ekonomi masyarakat lokal dapat dilihat pada Tabel 1.

Tabel 1. Local community social economi characteristic

\begin{tabular}{lllcc}
\hline No & Karakteristik & \multicolumn{1}{c}{ Kategori } & Jumlah & $\begin{array}{c}\text { Persentase } \\
(\%)\end{array}$ \\
\hline 1 & Umur & $23-40$ & 13 & 43.3 \\
& & $41-58$ & 12 & 40 \\
& & 59 & 5 & 16.7 \\
\hline 2 & Pendidikan & SD-SMP & 15 & 50 \\
& & SMA & 11 & 36.7 \\
& & Perguruan Tinggi & 4 & 13.3 \\
\hline 3 & Pekerjaan & Wiraswasta & 8 & 26.7 \\
& & PNS/Polri & 3 & 10 \\
& & Pegawai Swasta & 3 & 10 \\
& & Petani garam & 6 & 20 \\
& & Ojek & 6 & 20 \\
& & Tukang & 2 & 6.7 \\
\hline 4 & Jumlah anggota keluarga & Lainya & 2 & 6.7 \\
\hline & & $1-3$ orang & 15 & 50 \\
& & $4-6$ orang & 14 & 46.7 \\
\hline 5 & Lama tinggal (tahun) & $>6$ & 1 & 3.33 \\
\hline & & $<5$ & 0 & 0 \\
& & $5-15$ tahun & 3 & 10 \\
& & $>15$ tahun & 27 & 90 \\
\hline
\end{tabular}


Responden adalah masyarakat lokal yang bermukim di sekitar kawasan hutan mangrove. Sebagian besar usia masyarakat berkisar antara 23-40 tahun dengan persentase sebesar $43.3 \%$, diikuti dengan kisaran umur 41-58 tahun sebesar $40 \%$ dan usia $>59$ tahun dengan presentase $16.7 \%$. Persentase responden paling banyak berada pada usia produktif.

Menurut (Mugniesyah, 2006) umur yang berada di usia produktif memberikan peluang yang potensial bagi pengelolaan hutan mangrove yang partisipatif. Hal ini didasari atas kemampuan menyerap dan melakukan kegiatan partisipatif lebih besar kemungkinan berhasilnya pada usia produktif. Sedangkan menurut (Erwiantono, 2006), dengan usia yang relatif muda dan dengan produktivitas yang tinggi, masyarakat akan lebih mudah menerima masukan ataupun halhal baru yang bersifat untuk kemajuan dalam mengelola ekosistem hutan mangrove.

Dari segi tingkat pendidikan, sebesar 50\% masyarakat menamatkan pendidikan mereka pada bangku SDSMP, diikuti $36.7 \%$ menamatkan pendidikan pada bangku SMA dan sebanyak $13.3 \%$ menamatkan pendidikan sampai dengan Perguruan Tinggi. Tingkat pendidikan masyarakat setempat yang tergolong rendah ini dapat mengakibatkan pola berpikir dan bertindak masyarakat tersebut dalam mempertimbangkan sesuatu keputusan terbatas, terutama dalam pemanfaatan sumber daya alam yang ada di sekitarnya. Kondisi tingkat pendidikan yang rendah ini juga akan menjadi kendala dalam upaya partisipasi pengelolaan ekowisata mangrove. Hal ini akan dapat berimplikasi pada (1) rendahnya tingkat adopsi inovasi, (2) rendahnya partisipasi masyarakat dalam program pengembangan kawasan ekowisata, dan (3) perilaku yang tidak berwawasan lingkungan dalam berinteraksi dengan lingkungan hidupnya (Erwiantono, 2006).

Tingkat pendidikan juga mempengaruhi bagaimana individu berpartisipasi dalam suatu kegiatan. Disamping itu, tingkat pendidikan juga mempengaruhi motivasi dalam berpartisipasi (Rusdianti \& Satyawan, 2012). Menurut Tambunan et al. (2005) taraf pendidikan yang beragam akan memengaruhi daya nalar setiap individu, sehingga ada kemungkinan melakukan penafsiran yang berbeda terhadap program yang dilaksanakan dalam pengelolaan ekowisata mangrove. Sedangkan menurut Rahlem et al. (2017), perbedaan tingkat pendidikan setiap responden berpengaruh terhadap pola pikir dan partisipasi baik dalam mengelola maupun menjaga keberadaan wisata alam ini.

Jika ditinjau dari segi pekerjaan maka masyarakat yang dijadikan sebagai responden memiliki pekerjaan yang bervariasi. Ada yang bekerja sebagai pegawai swasta, buruh nelayan/tambak, wiraswasta, tukang, petani tambak, pedagang, guru, dan sopir. Hal tersebut menunjukan bahwa di kawasan pesisir Oesapa Barat tidak didominasi oleh 
aktivitas yang bercirikan pesisir tapi telah menunjukan perkembangan kegiatan usaha masyarakat yang bercirikan masyarakat perkotaan seperti sektor perdagangan dan lain sebagainya

Ditinjau dari segi penghasilan, maka kondisi sosial ekonomi masyarakat dari aspek pendapatan tergolong kelompok masyarakat miskin (Ritohardoyo \& Ardi, 2011). Sebesar 50\% masyarakat berpenghasilan di bawah Rp 1.500.000,00. Pendapatan dapat mempengaruhi partisipasi masyarakat dalam mengelola lingkungan hidup, dengan tingkat pendapatan yang lebih baik atau tinggi dapat mendorong seseorang berpartisipasi lebih baik atau tinggi pula (Erwiantono, 2006). Lama tinggal responden pada wilayah penelitian rata-rata di atas 15 tahun dan merupakan suku asli yang mendiami Provinsi Nusa Tenggara Timur.

\section{Persepsi Masyarakat Terhadap Hutan Mangrove}

Kajian mengenai pengetahuan masyarakat terhadap hutan mangrove ditinjau berdasarkan manfaat ekologis dan manfaat sosial ekonomi hutan mangrove. Hasil penelitian menunjukkan bahwa persepsi responden yang tinggal disekitar kawasan ekowisata berada pada kategori positif.

Berdasarkan hasil wawancara dengan responden terkait pengetahuan masyarakat tentang hutan mangrove sangat tinggi. Hal ini nampak dari jawaban mereka bahwa hutan mangrove hanya dapat ditumbuhi beberapa jenis mangrove secara alami. Dari hasil wawancara diketahui bahwa masyarakat secara umum mengetahui tentang pentingnya hutan mangrove bagi kehidupan mereka. Hal ini tampak dari jawaban mereka bahwa hutan mangrove dapat menahan abrasi dan dapat menahan angin kencang serta mengetahui bahwa hutan mangrove sebagai tempat pemijahan dan penyedia makanan bagi udang, kepiting dan ikan dan hewan laut lainnya. Persepsi masyarakat terhadap hutan mangrove disajikan pada Tabel 2.

Tabel 2. Local community perception of mangrove benefit

\begin{tabular}{llcc}
\hline \multirow{2}{*}{ No } & \multicolumn{1}{c}{ Kategori } & n & Responden \\
\cline { 3 - 4 } & & 0 & Persentase (\%) \\
\hline 1 & Sangat negative & 0 & 0 \\
2 & Negatif & 30 & 100 \\
3 & Positif & 0 & 0 \\
4 & Sangat positif & 30 & 100 \\
\hline
\end{tabular}

Secara keseluruhan responden masyarakat yang tinggal disekitar kawasan ekowisata, mengetahui bahwa hutan mangrove memiliki potensi untuk di kembangkan menjadi kawasan wisata, tempat penelitian dan pendidikan namun pemahaman responden masih sangat terbatas terkait ekowisata, kurangnya informasi dan sosialisasi tentang manfaat dan tujuan ekowisata menyebabkan responden acuh terhadap keberadaan ekowisata.

Persepsi masyarakat tentang pemanfaatan kayu atau batang pohon 
mangrove sebagai kayu bakar dan bahan bangunan cukup tinggi namun masyarakat sudah tidak lagi memanfaatkan batang pohon mangrove sebagai bahan bangunan. Hal ini dikarenakan adanya aturan oleh pemerintah setempat yang melarang masyarakat untuk mengambil sumber daya yang berada dalam kawasan mangrove tersebut.

Peraturan Daerah (perda) Kota Kupang No 21 tahun 2007 tentang Pengelolaan Wilayah Pesisir terutama pasal 64 ayat 1 mengatakan bahwa Setiap orang dan/atau penanggung jawab kegiatan yang tidak melaksanakan kewajiban sebagaimana dimaksud dalam Pasal 23, Pasal 32, Pasal 33, Pasal 34, dan Pasal 45 sehingga yang merusak lingkungan diancam dengan pidana kurungan paling lama 6 (enam) bulan dan denda paling banyak Rp 50.000.000 (Lima Puluh Juta Rupiah) namun Peraturan Daerah (perda) tentang pengelolaan ekowisata mangrove sampai saat ini belum dikeluarkan oleh Pemerintah Kota Kupang. Sebelum kawasan mangrove ini dikelola sebagai daerah ekowisata, masyarakat dapat secara leluasa mengambil sumberdaya yang ada untuk pemenuhan kebutuhan hidup mereka setiap hari.

Secara keseluruhan persepsi responden berada pada kategori positif tentang fungsi mangrove, hal ini dapat menjadi dasar bagi pemangku kepentingan untuk meningkatkan partisipasi masyarakat dengan meningkatkan pemahaman dan kesadaran masyarakat tentang fungsi dan manfaat ekowisata mangrove. kegiatan pembinaan dapat berupa penyuluhan secara berkesinambungan atau diskusidiskusi yang bersifat formal maupun informal. Melalui pembinaan diharapkan dapat meningkatkan pengetahuan dan pemahaman masyarakat terhadap arti pentingnya ekowisata mangrove, selanjutnya diharapkan terjadi peningkatan kesadaran untuk turut berpartisipasi dalam pengelolaan ekowisata mangrove.

\section{Partisipasi masyarakat lokal dalam pengelolaan ekowisata mangrove}

Dalam pengelolaan ekowisata mangrove, salah satu aspek penting yang sangat menentukan dalam keberlanjutan pengelolaan kawasan tersebut adalah masyarakat setempat. Hal ini disebabkan karena masyarakat setempat sangat tergantung kepada kondisi dan potensi sumberdaya alam serta lebih merasakan dampak di kawasan tersebut, atau dengan kata lain baik buruknya pengelolaan ekowisata mangrove tergantung dari partisipasi masyarakat setempat (Erwiantono, 2006). Berdasarkan hasil wawancara menunjukkan bahwa partisipasi masyarakat sekitar dalam pertemuan untuk merencanakan kegiatan dalam pengelolaan ekowisata mangrove sangat rendah. Hal ini dikarenakan beberapa kali aparat desa setempat mengadakan pertemuan bersama masyarakat, tetapi yang hadir dalam pertemuan tersebut hanya orang-orang tertentu saja. Banyak masyarakat yang tidak mendapat informasi bahwa akan dilaksanakan pertemuan. Pernyataan ini dikemukakan oleh beberapa warga yang bermukim di sekitar kawasan mangrove. 
Berdasarkan hasil wawancara dengan masyarakat sekitar pada tahap perencanaan dalam pengelolaan ekowisata mangrove masyarakat sekitar tidak terlibat dalam tahapan tersebut. Dari 30 responden masyarakat sekitar yang diwawancarai tidak ada satu orangpun yang terlibat dalam membuat rencana kegiatan, pengambilan keputusan, memberikan saran ataupun masukan dalam mengelola ekowisata mangrove. Hal ini disebabkan oleh karena Pemerintah dalam hal ini Dinas terkait yang menentukan bagaimana kegiatan pengelolaan dilakukan. Menurut Sadono (2012) dalam penelitiannya, peran serta masyarakat sekitar kawasan konservasi dapat berjalan dengan baik apabila masyarakat sekitar kawasan dapat mengetahui informasi rencana kegiatan pengelolaan, menyatakan pendapat atau saran mengenai kebijakan pengelolaan dan dilibatkan dalam pelaksanaan serta pengawasan kegiatan. Tingkat partisipasi masyarakat dalam pengelolaan ekowisata mangrove dapat dilihat pada Tabel 3.

Tabel 3. Level participation of local community at planning and implementation in the management of mangrove ecotourism

\begin{tabular}{cccc}
\hline Tingkat partisipasi & Kategori & n & $\begin{array}{c}\text { Responden } \\
\text { Persentase }\end{array}$ \\
\hline \multirow{3}{*}{ Tahap perencanaan } & Rendah & 30 & 100 \\
& Sedang & 0 & 0 \\
& Tinggi & 0 & 0 \\
& Total & 30 & 100 \\
\hline \multirow{3}{*}{ Tahap pelaksanaan } & Rendah & 24 & 80 \\
& Sedang & 6 & 20 \\
& Tinggi & 0 & 0 \\
& Total & 30 & 100 \\
\hline
\end{tabular}

Berdasarkan hasil wawancara ada juga masyarakat yang mengatakan bahwa mereka tidak mendapat informasi bahwa akan dilaksanakan sosialisasi tentang perencanaan pembukaan kawasan ekowisata mangrove. warga juga tidak diajak berembuk mengenai pengembangan ekowisata sehingga menimbulkan pandangan yang kurang baik dari sebagian warga yang menganggap kurang sopan karena tidak melalui jalur yang seharusnya dan warga masih memegang tradisi "sungkan" jika tidak diajak tidak ikut sehingga warga hanya bersikap biasa saja dan mendukung adanya ekowisata mangrove di daerah mereka. berdasarkan hasil wawancara dengan pihak pengelola, warga tidak diajak karena pihak pengelola sudah pernah mengajak warga tapi warga sendiri besikap acuh. Pihak pengelola juga berpendapat jika semua masyarakat ikut terlibat mengelola ekowisata maka akan sulit membagi hasil dari ekowisata tersebut.

Tingkat partisipasi pada tahap pelaksanaan merupakan keikutsertaan responden ataupun masyarakat yang terlibat dalam kegiatan pengelolaan ekowisata mangrove. Tahap pelaksanaan ini diukur dengan kehadiran dan keterlibatan masyarakat dalam kegiatan- 
kegiatan yang ada dalam ekowisata mangrove di Kelurahan Oesapa Barat seperti pemeliharaan area tracking mangrove, pemeliharan kebersihan ekowisata mangrove dan penanaman anakan mangrove.

Berdasarkan hasil wawancara, beberapa responden pernah ikut berpartisipasi dalam kegiatan yang dilakukan dikawasan ekowisata mangrove seperti terlibat dalam kegiatan pembersihan atau kerja bakti dilokasi ekowisata atau terlibat dalam kegiatan penanaman mangrove namun tidak secara rutin. Rendahnya partisipasi dalam kegiatan yang dilakukan di ekowisata mangrove dikarenakan masyarakat tidak mendapat pemberitahuan dari pihak pengelola bahwa akan diadakan kegiatan-kegiatan tersebut, hal ini juga dibenarkan oleh pihak pengelola bahwa pihak pengelola tidak menyampaikan informasi tentang kegiatan-kegiatan yang dilakukan di lokasi ekowisata. Menurut pihak pengelola mereka sudah pernah mengajak masyarakat sekitar untuk ikut dalam kegiatan namun masyarakat tidak hadir, sehingga pada kegiatan-kegiatan selanjutnya masyarakat tidak diberitahu. Menurut (Wardojo, 1992) partisipasi adalah keikutsertaan masyarakat baik dalam bentuk pernyataan maupun kegiatan. Keikutsertaan tersebut terbentuk sebagai akibat terjadinya interaksi sosial antara individu atau kelompok masyarakat yang lain dalam pembangunan. Partisipasi masyarakat dalam pembangunan merupakan kerjasama yang erat antara perencana dan masyarakat dalam merencanakan, melaksanakan, melestarikan dan mengembangkan hasil pembangunan yang telah dicapai.

Berdasarkan Tabel 3 dapat dilihat bahwa tingkat partisipasi pada tahap perencanaan dan tahap pelaksanaan masuk dalam kategori rendah. Salah satu faktor yang penting untuk dipertimbangkan dalam partisipasi adalah kemampuan individu untuk ikut serta dalam suatu kegiatan terutama yang membutuhkan tenaga dan waktu. Berdasarkan hasil wawancara dengan responden masyarakat, mereka tidak ikut berpartisipasi karna responden harus bekerja siang dan malam untuk menghidupi keluarganya sehingga tidak mempunyai cukup waktu untuk ikut berpartisipasi. Menurut Tenriawaruwaty et al. (2013), pekerjaan dan penghasilan yang baik dan mencukupi kebutuhan sehari-hari dapat mendorong seseorang untuk berpartisipasi dalam kegiatankegiatan masyarakat. Pengertiannya bahwa untuk berpartisipasi dalam suatu kegiatan, harus didukung oleh suasana yang mapan perekonomian.

Aspek pengetahuan dan keahlian merupakan salah satu faktor yang diduga berkontribusi pada keikutsertaan masyarakat dalam suatu kegiatan. Mayoritas responden tidak memiliki pengetahuan dan keahlian dalam hal teknis penanaman mangrove dan pembibitan. Sebagian kecil lainnya mengetahui teknis penanaman dan pembibitan berdasarkan informasi dari teman yang terlibat kegiatan rehabilitasi mangrove maupun yang terlibat langsung. 


\section{Faktor Eksternal Pendorong Partisipasi Masyaraka}

Faktor eksternal merupakan faktor yang berasal dari luar diri individu atau bisa disebut juga berasal dari lingkungan sekitar. Pada penelitian ini faktor eksternal yang dimaksud adalah pandangan responden tentang keaktifan pemerintah dan pihak pengelola dalam pengelolaan ekowisata yaitu bagaimana pandangan responden terhadap pengelola dalam menyampaikan informasi, ajakan serta dorongan kepada masyarakat agar terlibat dalam kegiatan pengelolaan mangrove

Berdasarkan hasil wawancara yang didapatkan, beberapa responden mengatakan bahwa pemerintah dan pihak pengelola kegiatan sudah memberikan sosialisasi mengenai sebagian kegiatan yang dilakukan pada pengembangan ekowisata mangrove, namun untuk kegiatan inti yang dilakukan dengan rutin seperti perawatan area tracking maupun kebersihan kawasan, masyarakat jarang diajak atau diberikan motivasi untuk terlibat. Pemberian motivasi kepada masyarakat cenderung dilakukan ketika ada acara besar seperti acara HUT kemerdekaan RI, Hari Konservasi Alam Nasional yang melibatkan instansiinstansi pemerintahan, pelajar, mahasiswa, tokoh pemuda dan tokoh masyarakar.

Keaktifan pengelola kegiatan berada pada kagetori sedang. Berdasarkan hasil wawancara dengan responden diketahui bahwa informasi yang diberikan mengenai kegiatan-kegiatan yang dilakukan di kawasan ekowisata mangrove hanya disampaikan pada saat rapat dan pertemuan yang biasanya hanya dihadiri oleh pengelola kegiatan, kurangnya informasi yang disampaikan kepada masyarakat yang tidak mengikuti rapat ataupun pertemuan, menimbul pemikiran bahwa kegiatan yang dilakukan hanya wajib bagi pengelola kegiatan saja.

Pihak pengelola mengatakan bahwa saat mengadakan sosialiasi kepada masyarakat hanya sebagian kecil warga yang datang, sehingga pada kegiatankegiatan selanjutnya dari pihak pengelola tidak melibatkan masyarakat. Menurut Girsang (2011) dalam penelitiannya menyatakan bahwa keaktifan tim pengelola kegiatan merupakan faktor pendorong yang mempengaruhi partisipasi masyarakat, salah satu hal yang dapat dilakukan pengelola kegiatan untuk meningkatkan partisipasi masyarakat adalah dengan melakukan sosialisasi mengenai kegiatan tersebut pada masyarakat. Sedangkan menurut Erawati \& Mussadun (2013) menyatakan bahwa adanya sosialisasi yang dilakukan oleh pengelola kegiatan mengenai manfaat kegiatan yang berhubungan dengan pengembangan kawasan mangrove akan memunculkan kepedulian masyarakat untuk ikut berpartisipasi dengan sukarela.

\section{KESIMPULAN}

Berdasarkan hasil penelitian, dapat disimpulkan bahwa tingkat partisipasi masyarakat dalam pengelolaan ekowisata mangrove Oesapa Barat berada pada kategori rendah, sedangkan persepsi masyarakat tentang fungsi ekosistem 
mangrove berada pada kategori positif. Hal ini dapat menjadi dasar bagi pemangku kepentingan untuk meningkatkan partisipasi masyarakat dengan meningkatkan pemahaman dan kesadaran masyarakat tentang fungsi dan manfaat ekowisata mangrove.

\section{UCAPAN TERIMA KASIH/ ACKNOWLEDGEMENT}

Penulis mengucapkan terimakasih kepada pihak LPDP dan Kemenristek Dikti yang telah membiayai penelitian ini. Penulis mengucapkan terima kasih kepada Dinas Kelautan dan Perikanan Kota Kupang, kepada Pemerintah Kelurahan Oesapa Barat, pihak pengelola ekowisata yang sudah memberikan izin untuk melakukan penelitian di kawasan Ekowisata Mangrove Oesapa Barat, dan kepada seluruh responden masyarakat yang telah meluangkan waktu guna membantu peneliti dalam penelitiannya.

\section{DAFTAR PUSTAKA}

BPHM Wilayah I Bali. (2011). Statistik Pembangunan. Balai Pengelolaan Hutan Mangrove Wilayah I, Denpasar - Bali.

Erawati, I., \& Mussadun. (2013). Partisipasi masyarakat dalam pengelolaan sumber daya lingkungan mangrove di desa bedono, Kecamatan Sayung. Jurnal Ruang; 01 (01):31-40.

Erwiantono. (2006). Kajian Tingkat Partisipasi Masyarakat dalam Pengelolaan Ekosistem Mangrove di Kawasan Teluk PangpangBanyuwangi (The community participation in mangrove ecosystem managementin Pangpang Bay, Muncar Banyuwangi). EPP, 3:44-50.
Girsang, J. (2011). Faktor yang mempengaruhi partisipasi masyarakat dalam kegiatan perbaikan jalan. Fakultas Ekologi Manusia. IPB. Bogor

Lio, F., \& Stanis. (2017). Partisipasi masyarakat dalam pelestarian hutan mangrove di kelurahan Oesapa Barat Kota Kupang. Kawistara, 7(3):207-314.

Mugniesyah. (2006). Peranan penyuluhan pertanian dalam pembnagunan pertanian. Bogor (ID): IPB Press.

Peraturan Daerah Kota Kupang No 21 tahun 2007 tentang Pengelolaan Wilayah Pesisir.

Pitana, I., Gede \& Putu, Gayatri. (2005). Sosiologi Pariwisata. Yogyakarta: Penerbit Andi.

Rahlem, D., Yoza, D., \& Arlita, T. (2017). Perception visitors and participation of society in the management of ecotourism in aek martua in rokan hulu. JOM Faperta.4(1).

Ritohardoyo, S., \& Ardi. (2011). Arahan kebijakan pengelolaan hutan mangrove: kasus pesisir Kecamatan Teluk Pakedai Kabupaten Kubu Raya Provinsi Kalimantan Barat. Jurnal Geografi, 8: 83-94.

Rusdianti \& Satyawan. (2012). Konversi lahan hutan mangrove serta upaya penduduk lokal dalam merehabilitasi ekosistem mangrove. Jurnal Sosiologi Pedesaan. 6: 1-17.

Sagala, N., \& Pellokila. (2019). Strategi pengembangan ekowisata hutan mangrove di kawasan pantai oesapa. Jurnal Tourism. 2(1):4763. 
Saputra, R. (2017). Strategi Pengembangan dan Pengelolaan Ekowisata Mangrove Kota Rebah Sei Carang Tanjungpinang Kepulauan Riau. [Tesis]. Universitas Maritim Raja Ali Haji.

Singarimbun, M., \& Effendi, S. (1987). Metode penelitian survei. Yogyakarta (ID): LP3ES.

Siregar. (2013). Metode penelitian kuantitatif. Jakarta (ID): PT Fajar Interpratama Mandiri.

Sugiyono. (2014). Metode Penelitian Kuantitatif Kualitatif dan R \& D. Alfabeta. Bandung.

Surya. (2009). Hampir Sekitar 10.000 Hutan Bakau NTT Rusak. <dalam antaranews.com>

Tenriawaruwaty, A., Didi, R,. \& Darmawan, S. (2013). Partisipasi masyarakat dalam pengelolaan sumberdaya air secara berkelanjutan di Kabupaten Bulukumba. e_jurnal Program Pascasarjana Universitas Hasanuddin.

Tim International Fund ForAgricultural Development. (2016). Inventroy sumberdaya wilayah pesisir Kelurahan Oesapa Barat Kecamatan Kelapa Lima Kota Kupang Nusa Tenggara Timur. http://ccdp-ifad.

Wardojo. 1992. Pendekatan Pennyuluhan Pertanian Untuk Meningkatkan Partisipasi Masyarakat. Dalam: Penyuluhan Pembngunan di Indonesia Menyongsong abad XXI. Pustaka Pembangunan Swadaya Nusantara. Jakarta (ID) 